\title{
A NON COGNATE ORIGIN FOR THE GIBEON KIMBERLITE MEGACRYST SUITE.
}

$$
\text { G.R. } \text { Davies }^{(1)} \text {;A.J. Spriggs }{ }^{(2)} \text {; P.H. Nixon }{ }^{(2)} \text { and D.C. Rex }{ }^{(2)} \text {. }
$$

(1) Department of Geological Sciences, The University of Michigan, Ann. Arbor, MI 48109; (2) Department of Earth Sciences, University of Leeds LS2 9JT, U.K.

The Gibeon kimberlite province, Namibia, occupies an area 100 by $80 \mathrm{~km}$ centered at $25^{\circ} 30^{\prime} \mathrm{S}$ and $18^{\circ} \mathrm{E}$. In excess of 60 kimberlite pipes are known, and they tend to occur in NNE-SSW trending clusters. The kimberlite province is underlain by circum cratonic basement stabilized circa $2.1 \mathrm{Ga}$. Undersaturated volcanism in Namibia defines an approximate SW-NE lineament. Several workers have proposed that post-Karoo igneous activity in Namibia results from the migration of the Discovery and Vema hotspots beneath Namibia from 85 to 60 and 60 to 40 Ma respectively (e.g. Hartnady and Le Roex 1985). However, age determinations of the magmatic events have until now been poor precluding a rigorous assessment of this hypothesis.

Petrographically unaltered kimberlite samples were obtained from four drill cores that penetrated kimberlite pipes of hyperbyssal facies. Core samples were coarsely crushed and crustal and mantle xenolithic material removed. The petrology of each pipe is variable implying either a heterogeneous magma or that each pipe contains several different intrusions. Garnet and clinopyroxene megacrysts were collected from 7 diatreme facies kimberlites. Samples for isotope analysis were selected on the basis of their unaltered nature. The aim is to ensure that alteration has not disrupted parent-daughter relationships and that the megacrysts have not interacted with the host kimberlite which has trace element contents several order of magnitude higher than the megacrysts. All megacrystes were crushed, sieved and washed prior to hand picking under liquids and subsequently ultrasonically leached in $6 \mathrm{MHCl}$. $\mathrm{Sr}$ isotope analyses were not performed on garnet megacrysts due to their extremely low $\mathrm{Rb}$ and $\mathrm{Sr}$ contents $(<0.1 \mathrm{ppm})$ which makes them susceptible to alteration.

Previous workers (e.g. Mitchell, 1987) have established that Namibian diopside and garnet megacrysts have large compositional ranges and concluded that as a whole the megacryst suite is generated by cumulate processes during the fractional crystallization of several batches of magma. Each kimberlite pipe in the Gibeon Province has its own characteristic megacryst suite which may form two or more populations indicating a non-genetic origin.

In order to compare the $\mathrm{Sr}-\mathrm{Nd}-\mathrm{Pb}$ isotope systematics of the kimberlite and megacrysts the time of kimberlite eruption must be known to $\pm 10 \mathrm{Ma}$. Macrocrystic phlogopites were separated from the kimberlite and leached in $2 \overrightarrow{\mathrm{M} \mathrm{HCl}}$ for 10 minutes to remove any carbonate and have ${ }^{87} \mathrm{Rb} /{ }^{86} \mathrm{Sr}$ ratios that range from 6.7 to 92.7 and ${ }^{87} \mathrm{Sr} /{ }^{86} \mathrm{Sr}$ from 0.7106 to 0.7879 . Three $\mathrm{Rb}-\mathrm{Sr}$ mica-whole-rock ages range from 71.2 to $71.6 \mathrm{Ma}$ (one sample from an altered kimberlite yields an age of $64 \mathrm{Ma}$ ). Reid et al. (1990) recently reported a K-Ar age for the adjacent Gross Brukkaros alkaline complex of $77 \pm 2 \mathrm{Ma}$ and a $\mathrm{Rb}-\mathrm{Sr}$ mica age of 68 $\pm 2 \mathrm{Ma}$, ages that bracket our proposed kimberlite eruption age of $71.5 \mathrm{Ma}$.

The four kimberlite pipes have considerable variation in initial $\mathrm{Sr}$ and $\mathrm{Nd}$ isotope ratios; $\epsilon_{\mathrm{Nd}}$ +1.6 to $+4.0 ; \epsilon_{\mathrm{Sr}}-14$ to +10 . These data are comparable to group I kimberlites (e.g. Smith, 1983) to which the Namibian kimberlites have strong whole-rock chemical affinities. Pipe $\mathrm{K} 2$ has comparable $\mathrm{Nd}$ isotope ratios but higher ${ }^{87} \mathrm{Sr} /{ }^{86} \mathrm{Sr}$ ratios that trend to values more radiogenic than Group I kimberlites. Compared to other Namibian kimberlites and Group I kimberlites $\mathrm{K} 2$ is characterized by higher $\mathrm{Ba}, \mathrm{Rb}, \mathrm{Sr}, \mathrm{K}$ and $\mathrm{P}$ concentrations. These characteristics are not a consequence of crustal interaction, a process that would produce lower concentrations of $\mathrm{Sr}, \mathrm{Nb}, \mathrm{P}$ and LREE. The style of trace element enrichment (e.g., higher $\mathrm{K} / \mathrm{Nb}, \mathrm{K} / \mathrm{Ti}$ and $\mathrm{Ba} / \mathrm{Nb}$ ) is similar to, although less extreme than, Group II kimberlites which are also generally characterized by relatively radiogenic ${ }^{87} \mathrm{Sr} /{ }^{86} \mathrm{Sr}$ (Fraser et al., 1985).

Present day and initial $\mathrm{Pb}$ isotope ratios of Namibian kimberlites are characterized by relatively high ${ }^{207} \mathrm{~Pb} /{ }^{204} \mathrm{~Pb}$ and ${ }^{208} \mathrm{~Pb} /{ }^{204} \mathrm{~Pb}$ ratios comparable to Group I kimberlites. Pipe $\mathrm{K} 2$ is again transitional towards Group II kimberlite compositions in having less radiogenic 
${ }^{206} \mathrm{~Pb} /{ }^{204} \mathrm{~Pb}$. All Namibian kimberlites have high $\mu$ and $\kappa$ values (50 to 80,220 to 310 ). On a ${ }^{207} \mathrm{~Pb} /{ }^{204} \mathrm{~Pb}$ vs ${ }^{206} \mathrm{~Pb} /{ }^{204} \mathrm{~Pb}$ diagram initial $\mathrm{Pb}$ isotope ratios of all the kimberlites define an array with a slope sub-parallel to some S. Atlantic ocean islands (e.g. Bouvet). As a whole the initial $\mathrm{Pb}$ data of the kimberlites plots between the fields of $\mathrm{S}$. Atlantic islands. Clinopyroxene megacrysts have a restricted range in initial $\mathrm{Sr}$ and $\mathrm{Nd}$ isotope ratios $\left(\epsilon_{\mathrm{Nd}} 2.8\right.$ to $4.7, \epsilon_{\mathrm{Sr}}-10$ to -18$)$. $\epsilon_{\mathrm{Nd}}$ values are generally higher and $\epsilon_{\mathrm{Sr}}$ lower than the host kimberlites. On a $\mathrm{Sr}-\mathrm{Nd}$ isotope covariation diagram the megacrysts plot close to, or slightly below, the 'mantle array'. Only a clinopyroxene megacryst from the Deutsch Erde pipe plots within the field of Namibian kimberlites. The clinopyroxene megacrysts define three distinct groups; 1) Mukarob, ii) Hanaus and Koherab, iii) Deutsch Erde. Clinopyroxenes from these three regions show significant inter-group REE variation implying geographic variations in the source of the megacrysts.

The clinopyroxene megacrysts have large variations in $\mathrm{Pb}$ isotope ratios $\left(\mathrm{e} . \mathrm{g} .{ }^{206} \mathrm{~Pb} /{ }^{204} \mathrm{~Pb}\right.$ $18-19.5)$ and are characterized by relatively elevated ${ }^{207} \mathrm{~Pb} /{ }^{204} \mathrm{~Pb}$ and ${ }^{208} \mathrm{~Pb} /{ }^{204} \mathrm{~Pb}$ such that they plot above the NHRL. These data define approximate linear arrays with a relatively restricted range in ${ }^{207} \mathrm{~Pb} /{ }^{204} \mathrm{~Pb}$ but large variations in ${ }^{206} \mathrm{~Pb} /{ }^{204} \mathrm{~Pb}$ and ${ }^{208} \mathrm{~Pb} /{ }^{204} \mathrm{~Pb}$. Measured $\mathrm{U} / \mathrm{Pb}$ ratios of the clinopyroxene megacrysts are low compared to the host kimberlite $(\mu=1$ to 22$)$. Initial ${ }^{207} \mathrm{~Pb} /{ }^{204} \mathrm{~Pb}$ and ${ }^{206} \mathrm{~Pb} /{ }^{204} \mathrm{~Pb}$ are distinct from the kimberlites but are comparable with continental flood basalts from Namibia and Brazil (Hawkesworth et al., 1986).

The $\mathrm{Sr}-\mathrm{Nd}-\mathrm{Pb}$ isotope disequilibrium between the megacrysts and host kimberlites palpably rules out a simple cogentic relationship. Previous workers have noted apparent $\mathrm{Sr}-\mathrm{Nd}$ isotope disequilibrium but have either ascribed the isotopic differences to minor alteration or errected models that invoke the early precipitation of the megacryst suite from a 'protokimberlitic' melt followed by compositional change in the melt due to fractional crystallisation and assimilation (e.g. Jones 1987).

These models are very difficult to reconcile with several aspects of kimberlite chemical and isotopic compositions. First the chemical compositions of kimberlites record little evidence of the extraction of the megacryst suite. Fractionation of olivine would rapidly deplete the magma in $\mathrm{MgO}$ and $\mathrm{Ni}$, spinels $\mathrm{Ni}$ and $\mathrm{Cr}$, clinopyroxene fractionation deplete $\mathrm{Sc}$, garnet fractiontion deplete Sc and HREE. The LREE concentration of liquids calculated to be in equilibrium with the megacryst suite are at least a factor of 2 lower than the host kimberlite. In order to produce a two-fold increase in LREE concentrations requires the fractionation of $50 \%$ of the melt assuming that $\mathrm{La}$ is perfectly incompatible. Even if fractional crystallisation was coupled with significant assimilation of peridotite, the calculated degrees of fractionation appear too high to produce a liquid with a kimberlitic composition.

The topology of the $\mathrm{Sr}-\mathrm{Nd}-\mathrm{Pb}$ isotope diagrams helps to constrain possible source components in megacryst and kimberlite genesis. Sr/Nd ratios of most mantle derived magmas are within the range 10 to 20 (excluding subduction related volcanism) such that mixing lines between components on a $\mathrm{Sr}-\mathrm{Nd}$ isotope diagram are close to straight lines. In terms of their $\mathrm{Sr}-\mathrm{Nd}$ isotopes the kimberlites and megacrysts could be explained through some form of mixing process that involves a relatively depleted source (MORB or OIB component) and an enriched component (DUPAL-OIB). The Mukorob megacryst samples have relatively unradiogenic $\mathrm{Sr}$ isotope ratios such that they have characteristics transitional toward HIMU and EMI ocean islands (e.g. St Helena and Cape Verde). On Pb/Pb diagrams the megacryst suite forms arrays sub-parallel to some Atlantic ocean islands and has relatively high ${ }^{207} \mathrm{~Pb} /{ }^{204} \mathrm{~Pb}$ and ${ }^{208} \mathrm{~Pb} /{ }^{204} \mathrm{~Pb}$ ratios that are more extreme than Atlantic ocean islands with the 'DUPAL' isotope signature (e.g. Gough, Walvis Ridge and Cape Verde). In contrast HIMU islands generally have radiogenic ${ }^{206} \mathrm{~Pb} /{ }^{204} \mathrm{~Pb}$ and relatively $10 \mathrm{w}{ }^{207} \mathrm{~Pb} /{ }^{204} \mathrm{~Pb}$ and ${ }^{208} \mathrm{~Pb} /{ }^{204} \mathrm{~Pb}$. Consequently the $\mathrm{Sr}-\mathrm{Nd}-\mathrm{Pb}$ isotope systematics of the megacryst suite are only comparable to continental flood basalts from the Parana and Karoo.

The Gibeon kimberlite volcanism occurred between 7 and $10 \mathrm{Ma}$ after the passage of the Discovery hotspot (Hartnady and Le Roex, 1985). The kimberlites contain coarse garnet lherzolite xenoliths that, on the basis of geobarometry, were derived from the base of the lithosphere at $150 \mathrm{~km}$. If kimberlite volcanism were the product of a plume it would occur as the plume past beneath the region not 7 to $10 \mathrm{Ma}$ later. Initial $\mathrm{Sr}-\mathrm{Nd}-\mathrm{Pb}$ ratios of the kimberlites are different from Discovery and not simply related by the incorporation of MORB-like mantle into the plume suggesting there is no simple genetic relationship. The 
similar ages do, however, suggest some form of relationship and we propose that heat transfer from the hotspot has caused melting of the asthenosphere-lithosphere boundary layer. This boundary layer which is in contact with the convecting asthenosphere will have a $\mathrm{Sr}-\mathrm{Nd}-\mathrm{Pb}$ isotope composition typical of the ambient regional mantle. The kimberlites have initial $\mathrm{Sr}-\mathrm{Nd}-\mathrm{Pb}$ ratios similar to an average composition of the $\mathrm{S}$. Atlantic ocean islands whose hotspot traces have passed beneath southern Africa (Gough, Bouvet, Shona and Tristan) compatible with melting of the asthenosphere-lithosphere boundary layer that has been modified by periodic hotspot related magmas.

The megacryst suite crystallised in the lithosphere from an alkali basalt derived from an asthenospheric source with isotope characteristics comparable to $\mathrm{S}$. Atlantic islands such as Bouvet and Ascension. Due to the low trace element contents of the 'cumulates' they record evidence of variable equilibration with 'DUPAL-like' sub-continental lithosphere that was the source of Karoo volcanism. The product has relatively high $\mathrm{Sm} / \mathrm{Nd}$ and low $\mathrm{m}$ and $\mathrm{Rb} / \mathrm{Sr}$ so that with time the suite records growth in radiogenic ${ }^{143} \mathrm{Nd}$ but little change in $\mathrm{Sr}$ and $\mathrm{Pb}$ isotope ratios. The megacryst suite was probably formed by the hotspot related activity that is thought to produce the Karoo-Parana flood basalts. The Gibeon Group 1 kimberlites were produced later and their higher trace element contents record less evidence of interaction with the lithosphere and consequently have less 'DUPAL' signature. The exception being K2 which assimilated lithosphere with a 'DUPAL' signature and fractionated to produce kimberlites with a more evolved major element composition.

$\mathrm{Sr}-\mathrm{Nd}-\mathrm{Pb}$ isotope analyses were also performed on unaltered material from three nonkimberlite localities; Dikker Willem carbonatite ( $49 \pm 1$ Ma, Reid et al., 1990), Schwarzeberg nephelinite $(30 \pm 1 \mathrm{Ma})$ and the Blue Hills monticellite peridotite associated with the Gross Brukkaros carbonatite (68-77 Ma, Reid et al., 1990). All samples plot below the mantle array on a Sr-Nd isotope diagram, the Dikker Willem carbonatite being the most divergent. The Blue hills and Schwarzeberg samples have $\mathrm{Sr}-\mathrm{Nd}$ isotope systematics comparable to the group 1 Namibian kimberlites. All the alkaline volcanics have very radiogenic initial ${ }^{208} \mathrm{~Pb} /{ }^{204} \mathrm{~Pb}$ and ${ }^{207} \mathrm{~Pb} /{ }^{204} \mathrm{~Pb}$ ratios so that they plot above the NHRL and the Gibeon kimberlites and megacrysts on $\mathrm{Pb}-\mathrm{Pb}$ diagrams. The alkaline volcanism is characterised by $\mu$ values higher than the kimberlites $(125-150)$. The $\mathrm{Pb}$ isotope signatures are more radiogenic than the Etendeka volcanism. However, age correction to $121 \mathrm{Ma}$, the time of Etendeka volcanism, lowers ${ }^{206} \mathrm{~Pb} /{ }^{204} \mathrm{~Pb}$ and ${ }^{207} \mathrm{~Pb} /{ }^{204} \mathrm{~Pb}$ ratios to values comparable to EtendekaParana volcanism. Alkaline volcanism occurred between 5 and $30 \mathrm{My}$ af ter the passage of the Vema and Discovery hotspots. The large apparent SCL signature recorded by the volcanism is consistent with conduction of heat from the plumes into the lithosphere causing melting. Preliminary conduction modelling suggests that following the passage of a plume the bottom 10 to $20 \mathrm{~km}$ of the lithosphere will be heated by circa $50^{\circ} \mathrm{C}$ within $10 \mathrm{My}$ consistent with Namibian alkaline volcanism being derived from the lithosphere.

Fraser K.J., Hawkesworth C.J., Erlank A.J, Mitchell R.H. and Scott-Smith B.H. 1985. Sr,Nd and $\mathrm{Pb}$ isotopes and trace elements of lamproites and kimberlites. Earth Planet. Sci. Lett. 76, $57-70$.

Hartnady C.J. and Le Roex A.P. 1983. Southern Ocean hotspot tracks and the Cenozoic absolute motions of the African, Antartic and South American plates. Earth Planet. Sci. Lett. $75,245-57$.

Hawkesworth C.J., Mantovani M.S.M., Taylor P.N. and Palacz Z. 1986. Evidence from the Parana of south Brazil for a continental contribution to Dupal islands. Nature 322, 356-59.

Jones R.A. 1987. Sr and Nd isotopic and REE evidence for the genesis of megacrysts in kimberlites of southern Africa. In Nixon P.H. Mantle Xenoliths.

Mitchell R.H. 1987. Megacrysts in kimberlites from the Gibeon field, Namibia. Neues Jahrbuch Miner. 157, 267-283.

Reid D.L., Cooper A.F., Rex D.C. and Harmer R.E. 1990. Timing of post-Karoo alkaline volcanism in southern Namibia. Geol. Mag. 127, 427-433.

Smith C.B. 1983. Pb, $\mathrm{Sr}$ and Nd isotopic evidence for sources of southern African Cretaceaou kimberlites. Nature 304, 51-54. 